\title{
THEORETICAL BASES OF THE \\ ORGANIZATION OF EFFECTIVE \\ FINANCIAL MAINTENANCE OF THE \\ ENTERPRISES-EXPORTERS
}

Miraziz Makhmudov

Researcher of Tashkent State University of Economics, Republic of Uzbekistan

\section{Crossref}

Issue DOI http:/ /dx.doi.org/10.26739/2433-202x-2017-8-8

Article DOI http://dx.doi.org/10.26739/2433-202x-2017-8-8-5

Abstract: The article discusses the theoretical bases for the organization of effective financial support for exporting enterprises in the context of increasing competition in the world markets for the sale of goods and services. The solution to the problem of increasing the efficiency of exporting enterprises depends largely on the availability of efficient search mechanisms and the attraction of financial resources for the expansion export potential.

Keywords: theory, organization, efficiency, financial security, exporting enterprises, financial resources. 
In the context of growing competition in the world markets for the sale of goods and services, the solution to the problem of increasing the efficiency of exporting enterprises depends largely on the availability of efficient search mechanisms and the attraction of financial resources for the needs of increasing their export potential.

The functioning of any exporting enterprise is inconceivable without a constant inflow of investments necessary for normal reproduction, constant updating of technologies, development of new types of products that are in demand in foreign markets. In addition to technical and technological renewal of production and development of new types of export products, they also need to update other areas of their activities related to the increase of export potential, including quality marketing research, the introduction of progressive methods of corporate governance, the organization of advertising of manufactured exports and the establishment of reliable channels for it marketing. All this requires constant improvement of the mechanism of investment provision of their innovative needs, from search and attraction, to the correct distribution and rational use of significant amounts of financial resources. [1]

The processes of organization of financing of exporting enterprises have a complex structure and are closely connected with the existing circulation of investment resources in the modern economy.

The concept of "investment" came from the Latin word investire - to clothe. Investments in the era of feudalism was the introduction of a vassal into possession of a feud. In the world-famous dictionary of Maximilian, investment means, "the flow of expenditure intended for the production of goods, not for direct consumption." In the Oxford Explanatory Dictionary this term is interpreted as "Acquisition of assets, for example, securities, works of art, deposits in banks or building societies ..., in order to obtain financial returns in the form of profit or capital increase." A.Marshall in his "Principles of Political Economy" explains the ability and propensity to save: "The ability to save depends on the excess of income over the necessary costs." [2]

The well-known Ukrainian scientist I.A. Blank interprets investments as: "Capital investment in monetary, material and non-material forms in the objects of entrepreneurial activity with a view to obtaining current income or ensuring the increase in its value in the future period". A prominent American scientist is an economist, winner of the Nobel Prize in Economics for 1990. W. Sharp believes that "investing" means "parting with money today 
in order to get a greater amount of money in the future" [3].

The growing importance of the investment market for financing exporting enterprises is due to the fact that it serves as an effective channel for accumulating the savings of individuals and legal entities with a view to transforming them into financial assets for later investing in the most competitive sectors of national economies. The release and sale of export products is precisely that vital area that attracts investors seeking to obtain a high return on their assets. A deeper understanding of the role of investment in increasing the export potential of enterprises is facilitated by the disclosure of the theoretical foundations for financing investment processes associated with the expansion of the spectrum and the increase in the scale of output of export products. At the same time, the mechanism of financing of exporting enterprises is understood as a set of practical actions for the search, attraction and use of investments for the implementation of programs to increase their export potential [4].

A correct understanding of the theoretical foundations of the problem of financing exporting enterprises is facilitated by the study of the works of John Maynard Keynes, an outstanding representative of the classical economic theory, who argued that the free market system lacks an internal mechanism that ensures macroeconomic equilibrium. However, in the context of globalization, modern market economy is becoming an open selfdeveloping system that acquires the capacity for self-regulation, which finds concrete expression in increasing the export potential of individual economic entities. Significant influence on the activation of the processes of increasing the export potential of key enterprises of national economies was provided by the ideas and postulates of the "Concept of Domination" that appeared after the Second World War in France, according to which a business entity playing a key role in ensuring the economic development of a particular region or in providing the basic industry of the national economy with a powerful "Dragging effect" represents a peculiar growth pole that generates the "agglomeration" effect.

The next important theory that justified the need for the state to increase the export potential of the national economy was the theory of regulation, developed in the early 1990s in the works of the French economist Robert Bouillier. The theory of regulation rejects the neoclassical idea that an optimal organization can guarantee a stable economic dynamics once and for all. Further deepening of research into the problems of intensifying the 
processes of attracting investment for the needs of innovative development of exporting enterprises was facilitated by the neoclassical theory of international capital flow that developed within the framework of the classical theory of international trade. Finally, the postulates of the neoclassical theory of the international capital movement were formulated in the first decades of the twentieth century by E. Heckscher and B. Olin, as well as R. Nurks and K. Iversen.

Later, neo-classical theory was replaced by the neo-Keynesian theory of international capital flow, which was based on the principles of macroeconomic analysis. R. Harrod, based on his model of "economic dynamics" has proved that the lower the rate of economic growth of a country rich in capital, the stronger the tendency to export capital from it. [5].

The rapid growth of the export potential of transnational corporations (TNCs) drew attention in the second half of the 20th century to them from the economic theory, which first studied this phenomenon within the framework of the theory of the firm. However, later, independent concepts began to be developed, based primarily on the ideas of American economists S. Heimer on the need for a firm to have advantages over local competitors when making direct investments abroad and $\mathrm{R}$. Coase about the existence of a specific market within a large corporation, and also R. Vernon, who in his concept of the life cycle of the product explained the phenomenon of TNCs [6].

Correct understanding of the reasons for the high competitiveness of exporting enterprises was facilitated by the emergence of a model of monopolistic advantages that was developed by S. Heimer and further developed by Ch. P. Kindleberger, R.E. Cavez, G.J. Johnson, R. Lacroix. It is based on the idea that for large corporations the maintenance of production at a sufficiently profitable level is possible due to the increase in export potential and the conquest of new markets.[7]

Another argument in favor of activating the activities of exporting enterprises is the product life cycle model developed by the American R. Vernon on the basis of the growth theory of the firm. In accordance with this model, any new product of the firm goes through five stages of the cycle of its life:

I stage - introduction to the market;

II stage - sales growth;

III stage - their maturity,

Stage IV - saturation of the market; 
V stage - a decline in sales.

The increase of export potential can prevent the company from being drawn into the last stage of the life cycle of its products by developing new markets for their sales abroad. Many significant motivations for the behavior of exporting companies are explained by J. Dunning's eclectic model, according to which the company starts the production of goods and services abroad due to the fact that three prerequisites simultaneously coincide:

1) the firm has advantages in comparison with other firms in this foreign country (specific advantages of the owner);

2) it is more advantageous for the firm to use these advantages on the spot, rather than selling them there by exporting goods or exporting knowledge to other firms (advantages of internationalization);

3 ) the company uses some production resources abroad more efficiently than at home, thanks to the opening advantages of the new location. Due to the high level of organization of financial markets in countries with developed market economies, the amount of investment allocated to exporting enterprises far exceeds the amount of financial resources received by other categories of economic entities.

In Table-1. Leading countries in terms of the volume of investment received for the needs of innovative development of enterprises, most of which are exporters of goods or services.

Table -1

Ten of the largest countries that make investments for the needs of innovative development of enterprises in 2014

(billion dolar USA.)

\begin{tabular}{|l|l|c|c|}
\hline \multirow{2}{*}{ Name of countries } & \multicolumn{2}{|c|}{ Including } \\
\cline { 3 - 4 } & & $\begin{array}{c}\text { Inflow } \\
\text { from }\end{array}$ & Total FDI \\
\hline 1 & USA & 232,865 & 2093,049 \\
\hline 2. & United Kingdom & 223,966 & 1347,688 \\
\hline 3. & China & 59,899 & 1184,471 \\
\hline 4. & France & 157,970 & 1026,081 \\
\hline 5. & Belgium & 40,628 & 748,110 \\
\hline 6. & Holland & 0,232 & 673,430 \\
\hline
\end{tabular}




\begin{tabular}{|c|l|c|c|}
\hline 7. & Germany & 50,925 & 629,711 \\
\hline 8. & Spain & 53,385 & 537,455 \\
\hline 9. & Canada & 108,655 & 520,737 \\
\hline 10. & Brazil & 34,585 & 328,455 \\
\hline
\end{tabular}

And the more efficient the work of financial markets and institutions, the easier it is for a specific enterprise, which is the bearer of the demand for investment capital, to gain access to free financial resources rotating on the market. Given these circumstances, the importance of acquiring knowledge of the theoretical foundations of organization of financing of investment projects of enterprises. [8]

The radical change of the economic system and the transition to a market economy model in the Republic of Uzbekistan contributed to a significant increase in the interest of Uzbek researchers in the problem of financing innovative development programs for exporting enterprises. However, in the domestic literature, the issues of financing programs to increase the export potential of enterprises have not yet become the subject of special study. Among the large-scale recent works, where the problems of using alternative methods of financing enterprises are more or less reflected, there are monographic studies by IL Butikova, DG Gazibekov and Sh. Sh. Shohazamiy. They used and summarized rich empirical material on the domestic stock market, on which the authors build a systematic picture of the current state of this mechanism, tools, problems and prospects for their development. From the point of view of the history of the formation of an effective mechanism of investment provision, the study of the basic conditions for its development, the genesis of its infrastructure, the works of Kotov VA, Khamidulina MB, Yuldasheva RZ, Yausheva RA are of considerable interest. and others. In them the authors turn to certain aspects of this mechanism that affect the efficiency of increasing the export potential of exporting enterprises.[9]

An analysis of the existing works of foreign and Uzbek scientists allows us to conclude that the problem of expanding the spectrum and increasing the scale of financing for exporting enterprises requires the efforts not only of state and industry management bodies, but also synchronized actions on the part of local authorities and institutes of investment and financial infrastructure. The process of building up the production and technical 
potential of exporting enterprises requires compliance with a number of mandatory conditions of regulatory, technical, financial, economic and organizational nature. 


\section{References:}

1. Business: Oxford Dictionary: -M .: Progress Academy; Publishing House of the RSUH, 1995. P.335

2. Blank IA Asset Management. -Kiev .: Izd. house "Nika-Center", 2002. With. 186.

3. Doronin I.G. World stock markets: the laws of development and the current state / IG Doronin / / Money and credit. -M .: 2002. - No. 9. - P. 58-64

4. Blank IA Asset Management. -Kiev .: Izd. house "Nika-Center", 2002. With. 236.

5. Humer St.H. The International Operation of National Firms, Cambridge, Mas: MIT Press, 1976, p. 34-38

6. Deeva A.I. Investments. Tutorial. - $\mathrm{M}$.: Exam, 2005. P. 40 - 46. 7. John H. Dunning. Toward an Eclectic Theory of International Production: Some Empirical Tests // Journal of International Business Studies. ITHAKA., 1980. -Vol. 11, No. 1, -pp. 9-31.

8. Butikov IL Market of securities: a textbook. -T .: Konsauditinform, 2001.472 p. Shokhazamy Sh.Sh. Financial market and securities. Textbook. In two vols. - T .: Iqtisod-Moliya, 2005. T.1. - 728.

9. Dictionary of modern economics Maximilian. - M.: INFRA-M, 1997. P. 258. 